The Egyptian Journal of Hospital Medicine (January 2021) Vol. 82 (2), Page 217-224

\title{
COVID-19 Quarantine Measures and Its Impact on Pattern of Life of School Children
}

\author{
Eman M. Araby*1, Ehab M. Emadeldin', Hany M. Zakaria ${ }^{3}$ \\ ${ }^{1}$ Department of Public Health and Community Medicine, Faculty of Medicine, Benha University- Egypt \\ ${ }^{2}$ Department of Physical Health Sciences, Faculty of Physical Education, Benha University- Egypt \\ ${ }^{3}$ Department of Educational Sciences and Psychological - Faculty of Physical Education - University of Benha - Egypt \\ *Corresponding author: Eman M. Araby, Mobile: (+20) 01017571492, E-Mail: dremanaraby77@ gmail.com
}

\begin{abstract}
Background: Although the physical effects of lockdown due to COVID-19 pandemic have become largely known, the psychological effects are still unknown. Objective: to investigate physical and psychological impact of quarantine measures among school children in Egypt. Methodology: This study investigated the impact of lockdown measures on eating, sleeping, mood and behavior of school children using online survey. Results: Total participants were 1507, aged between 6 to 14 years, private schools' students represented $60 \%$ of responders. $96.4 \%$ had changes in sleeping pattern, $77.8 \%$ had changes in eating pattern, $21.7 \%$ showed worries about general health condition, $70.5 \%$ had mood and behavioral changes especially aggressive behavior and finally, $37.3 \%$ had problems in concentration and focusing. Sociodemographic factors significantly affected sleeping of children during quarantine. Males were more affected considering bed time, $77.8 \%$ of those returned to bed wetting were girls, the most affected age group was $8-10$ years old , urban residents and the first ordered child were the most affected. Changes of eating pattern were more common among females, within the age group 8-10 years, first ordered child of families with sufficient monthly income. Those having one or both of his/her parents is a health care worker were significantly affected and had more worries about health. Finally, sex was the only factor affecting behavioral changes (male more than females). Conclusion: COVID-19 has a notable impact on eating, sleeping patterns as well as mood and behavior of the children.
\end{abstract}

Keywords: COVID-19, Lockdown, Impact, School-children.

\section{INTRODUCTION}

Quarantine means separating and restricting the movement of people who are potentially exposed to a contagious disease to ensure that they do not become infected and to reduce the risk of transmitting the disease to others ${ }^{(1)}$. COVID-19 quarantine measures like school terminations and movement restrictions has been used as a public health strategy to reduce disease transmission and it has overturned the lives millions globally, disrupted children's routines and support systems and added new stressors on parents who may have to go to work ${ }^{(2)}$.

COVID-19 pandemic and its quarantine measures have a strong impact on individuals mental health ${ }^{(3-5)}$. Separation from loved ones, loss of freedom, uncertainty about the health condition and illness can have significant effects; even cases of suicide have been reported. Also fear and anxiety about a new disease and what could happen can be overwhelming and cause strong emotions among adults and children ${ }^{(6)}$.

Longer durations of quarantine, insufficient data from public health authorities about purposes of isolate, increased worry about becoming infected or infecting others, inadequate access to regular medical care, restricted social contact with others, dissatisfaction due to loss of one's standard daily schedule, financial loss and shame or dismissal from others are strong stressors on parents related to quarantine and has strong impact on their children ${ }^{(7)}$.

The current study aims to investigate physical and psychological impact of quarantine measures among school children in Egypt.

\section{SUBJECTS AND METHODS}

Data were collected via an online survey using google forms. The link was shared to IT employee in the selected schools who in turn disseminated it widely through email, Facebook page of the school, WhatsApp and via partnerships. The survey was available from the $1^{\text {st }}$ to $31^{\text {st }}$ May 2020 . The total number of individuals participating in the survey during this time frame and completed it properly was 1507 participants. Schools shared in the survey were selected by stratified random sampling technique to have a representative sample from primary and preparatory schools at Qualubyia governorate weather governmental, private or international schools. The total sharing schools were 10 (3 preparatory and 7 primary).

Questions included in the survey were adopted and translated from CDC fact sheet about stressful effects of COVID-19 pandemic on children and teens, 2020. We asked about sociodemographic status of school children in addition to questions about: 
- Changes in sleep patterns (sleeping less or more than usual, difficulty falling asleep, waking in the middle of the night, avoiding bedtime, seeking out parents in the middle of the night, sleeping more (perhaps even through meals, daily routines, or fun activities, or taking frequent naps) and if young children return to bedwetting.

- Changes in eating patterns (eating less or more than usual, skipping meals, less interest in favorite foods, express feeling hungry all the time, even after eating).

- Increased aches and pains (experience headaches, upset stomach, and other aches and pains interfering with child ability to participate in daily routines or favorite activities).

- Increased focus on body and looking for evidence of illness (asking about their temperature, asking if they look sick, or spending a lot of their day checking their symptoms and evaluating whether or not they might be sick).

- Changes in mood and behavior (frequent tearfulness, sadness, irritability, anger, and fearfulness as well as increased oppositional, aggressive responses and arguing).

- Increased clinginess/difficulty separating (if children want to spend more time with and need extra hugs from their parents, distress when separating from parents, inability to sleep at night in their own room or bed or are unable to tolerate having parents out of view or in a different room).

- Increased worries/inability to focus (inability to complete school assignments or sit through a favorite movie or TV show, if the child spends a lot of his day talking about the current pandemic).

\section{Ethical approval:}

Ethical approval for the study was granted by Ethic Committee of Scientific Research of Benha Faculty of Medicine.

Data Privacy and Consent of Participation: During the informed consent process, survey participants were assured all data would be used only for research purposes. Participants' answers were anonymous and confidential according to Google's privacy policy (https://policies.google.com/privacy?hl=en). Participants were not permitted to provide their names or contact information. Additionally, participants were able to stop study participation and leave the questionnaire at any stage before the submission process; if doing so, their responses would not be saved. Responses were saved only by clicking on the provided "submit" button.

By completing the survey, participants acknowledged their voluntary consent to participate in this anonymous study. Participants were requested to be honest in their responses ${ }^{(8)}$.

\section{Statistical methods}

Data were verified, coded by the researcher and analyzed using IBM-SPSS Statistics for windows, version 23.0 (Copyright IBM Corp., Armonk, N.Y., USA. 2015). Descriptive statistics: Means, standard deviations, medians, ranges and percentages were calculated. Test of significances: chi-square test was used to compare the difference in distribution of frequencies among different groups. For continuous variables; independent t-test analysis was carried out to compare the means of dichotomous data. There was no specific calculation of the sample size. A significant p-value was considered when it is equal or less than 0.05 .

\section{RESULTS}

Total study participants were $1507,(16.1 \%)$ aged between 6 to $<8$ years, $(36.5 \%) 8$ to $<10$ years, $(20.4 \%)$ 10 to $<12$ years and (27\%) $12-14$ years old.(59.1\%) of studied children were males and $(40.9 \%)$ were females. The majority $(90.5 \%)$ were urban or semi-urban residents. Private schools' students represented about $(60 \%)$ of responders, while $(27.1 \%)$ from governmental schools and only (13.9\%) from international schools. $69.3 \%$ of parents were university graduates, $(23.4 \%)$ were post university graduates and only (7.3\%) were illiterate or averaged educated. (65.2\%) of parents mentioned that monthly income is sufficient to meet basic needs of the family, $(31.8 \%)$ their monthly income allows savings and (3\%) with insufficient income to meet basic needs. 19.7\% of parents were health care workers (physicians, dentist or pharmacist).

Figure 1 demonstrates that there were prominent changes regarding sleep, eating, daily activities, worries about health condition, mood and behavior and finally the concentration and focusing abilities among studied children. 


\section{Figure 1: Changes in sleep,eating,mood\&behavior}

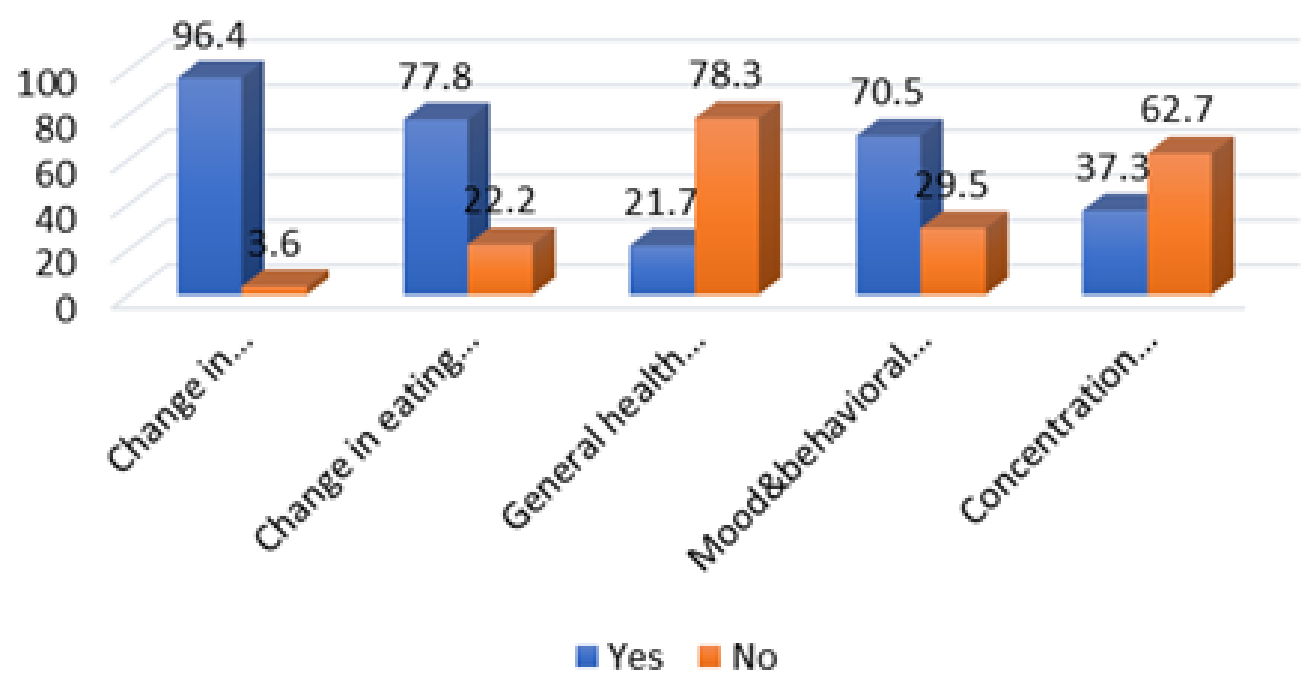

Figure 2 demonstrates the change of sleeping pattern among studied children.

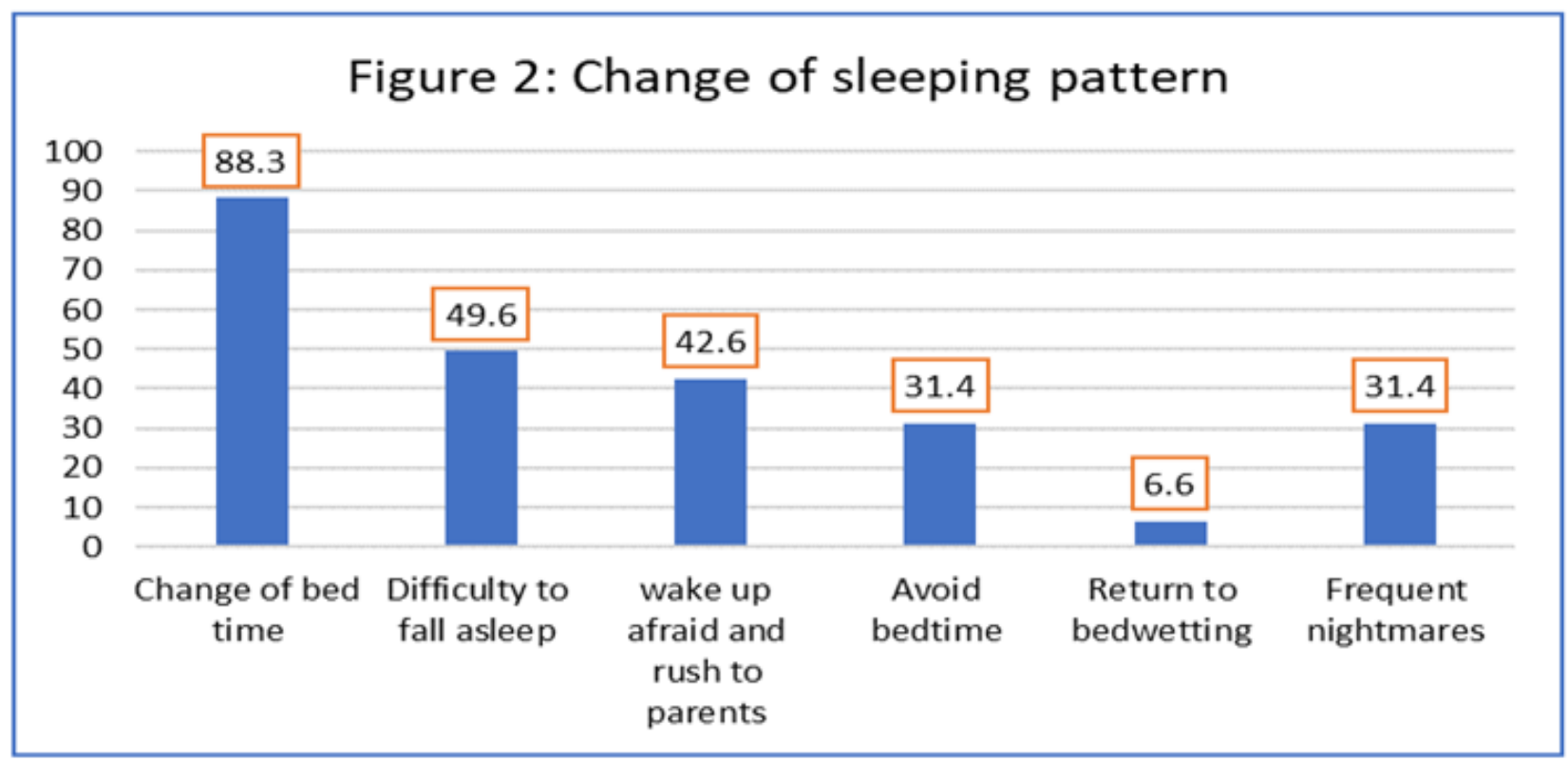

By reviewing the parents' answers about the changes in their children's sleeping pattern, we found that $(55.9 \%$ of boys vs. $46.4 \%$ of girls) slept more than usual, (55.6\% of boys vs. $35.7 \%$ of girls) took frequent naps and all these changes were statistically significant $\left(x^{2}=22.1, \mathrm{p}<0.001\right)$, unfortunately $6.6 \%$ of children returned to bedwetting and the majority of them $(77.8 \%)$ were girls $\left(x^{2}=22.1, \mathrm{p}<0.001\right)$, the most affected age group was $(8-10)$ years old $\left(x^{2}=35.9, \mathrm{p}<0.001\right)$, urban residents $\left(x^{2}=20, \mathrm{p}<0.001\right)$, families of 4 members $(55.6 \%)\left(x^{2}=16.2, \mathrm{p}=0.006\right)$. Regarding night mares, $(31.4 \%)$ of the children had frequent nightmares recently. Boys were significantly affected $(51.2 \%, \mathrm{p}<0.001), 10$ years old children $(\mathrm{p}<0.001)$, urban residents $(\mathrm{p}=0.02)$, four members families $(53.5 \%, \mathrm{p}<0.001)$ and first order child $(55.6 \%$, $\mathrm{p}<0.001)$ were the most affected groups. 
Table 1 and Figure 3 demonstrate that "eating more than usual" is the most notable change of eating pattern followed by ignoring some meals. These changes were significantly higher among females, 8-10 years old children, first ordered child of families with sufficient monthly income.

Table (1): Relation between sociodemographic factors and changes of eating pattern

\begin{tabular}{|c|c|c|c|c|}
\hline Variables & Yes $(\%)$ & No $(\%)$ & $x^{2}$ test & $P$-value \\
\hline $\begin{array}{l}\text { Sex } \\
\text { Male } \\
\text { Female } \\
\end{array}$ & $\begin{array}{l}49.7 \% \\
50.3 \% \\
\end{array}$ & $\begin{array}{l}91.9 \% \\
8.1 \% \\
\end{array}$ & 191.9 & $<0.001 * *$ \\
\hline $\begin{array}{l}\text { Age group } \\
6- \\
8- \\
10- \\
12-14\end{array}$ & $\begin{array}{l}17.2 \% \\
37 \% \\
18.8 \% \\
27 \%\end{array}$ & $\begin{array}{l}12.2 \% \\
34.6 \% \\
26.3 \% \\
26.9 \%\end{array}$ & 11.49 & $0.009 *$ \\
\hline $\begin{array}{l}\text { School } \\
\text { Governmental } \\
\text { Private } \\
\text { International } \\
\end{array}$ & $\begin{array}{l}26.6 \% \\
58.8 \% \\
14.6 \%\end{array}$ & $\begin{array}{l}28.4 \% \\
60.3 \% \\
11.3 \%\end{array}$ & 2.37 & 0.305 \\
\hline $\begin{array}{l}\text { Residence } \\
\text { Urban } \\
\text { Rural }\end{array}$ & $\begin{array}{l}90.4 \% \\
9.6 \%\end{array}$ & $\begin{array}{l}91 \% \\
9 \%\end{array}$ & 0.143 & 0.705 \\
\hline $\begin{array}{l}\text { Child's order } \\
\text { First } \\
\text { Middle } \\
\text { Last }\end{array}$ & $\begin{array}{l}52.5 \% \\
21.2 \% \\
26.3 \% \\
\end{array}$ & $\begin{array}{l}59.4 \% \\
20.9 \% \\
19.7 \% \\
\end{array}$ & 6.87 & $0.03 *$ \\
\hline $\begin{array}{l}\text { Income } \\
\text { Insufficient } \\
\text { Sufficient } \\
\text { Allow saving }\end{array}$ & $\begin{array}{l}2.7 \% \\
62.7 \% \\
34.6 \% \\
\end{array}$ & $\begin{array}{c}5.1 \% \\
64.8 \% \\
30.1 \%\end{array}$ & 6.08 & $0.04 *$ \\
\hline $\begin{array}{l}\text { Parent(s)is/are health care worker } \\
\text { Yes } \\
\text { No }\end{array}$ & $\begin{array}{l}20.3 \% \\
79.7 \%\end{array}$ & $\begin{array}{l}17.6 \% \\
82.4 \%\end{array}$ & 1.19 & 0.27 \\
\hline
\end{tabular}

*Significant...p $<.05 * *$ Highly significant.....p $<.001$

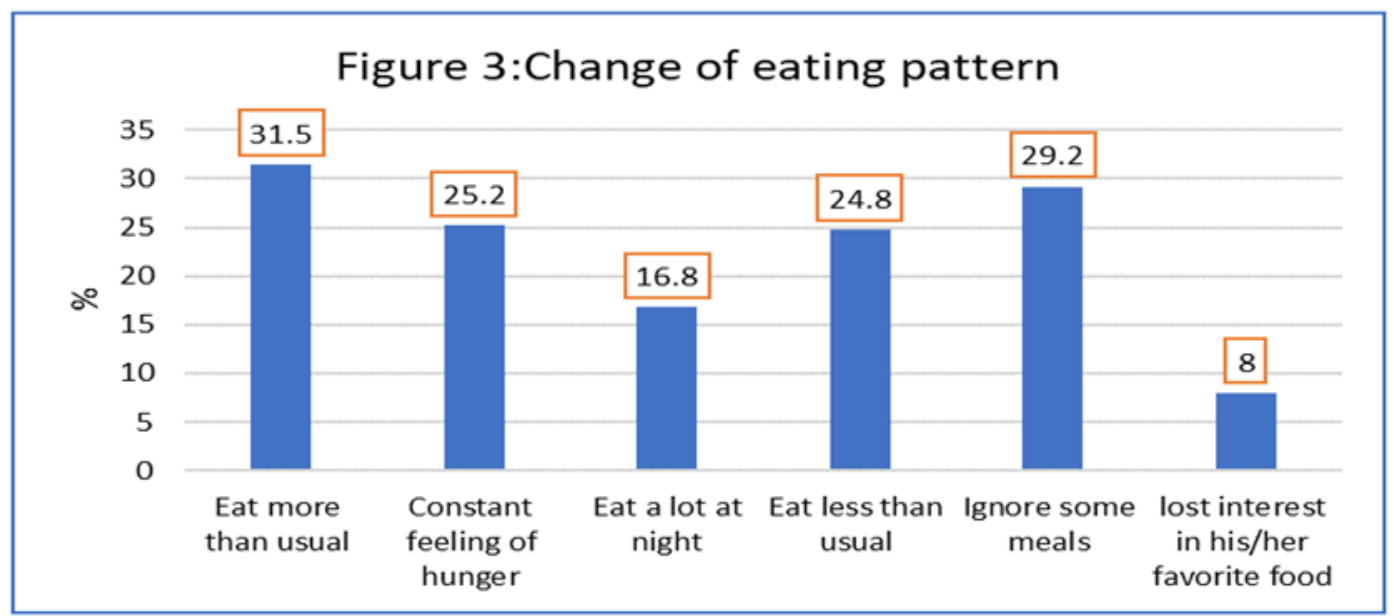

Table 2 and Figure 4 demonstrate that $21.7 \%$ of parents noticed worries of their children. These worries were expressed as inability to carryout the usual daily activity (45.7\%) and excessive handwashing and using sterilizers (43\%). Students of private schools or belonging to families with sufficient monthly income or whose parents are health care worker were significantly affected. 
https://ejhm.journals.ekb.eg/

Table (2): Relation between sociodemographic factors and worries about health condition

\begin{tabular}{|c|c|c|c|c|}
\hline $\begin{array}{l}\text { Worries about health } \\
\text { Socio-demographics }\end{array}$ & Yes (\%) & No (\%) & $x^{2}$ test & $P$-value \\
\hline $\begin{array}{l}\text { Sex } \\
\text { Male } \\
\text { Female }\end{array}$ & $\begin{array}{l}59.8 \% \\
40.2 \%\end{array}$ & $\begin{array}{l}58.9 \% \\
41.1 \%\end{array}$ & 0.069 & 0.792 \\
\hline $\begin{array}{l}\text { Age group } \\
6- \\
8- \\
10- \\
12-14\end{array}$ & $\begin{array}{l}18 \% \\
37.2 \% \\
20.1 \% \\
24.7 \%\end{array}$ & $\begin{array}{l}15.5 \% \\
36.3 \% \\
20.5 \% \\
27.7 \%\end{array}$ & 1.87 & 0.598 \\
\hline $\begin{array}{l}\text { School } \\
\text { Governmental } \\
\text { Private } \\
\text { International } \\
\end{array}$ & $\begin{array}{l}20.4 \% \\
63.1 \% \\
16.5 \%\end{array}$ & $\begin{array}{c}28.8 \% \\
58 \% \\
13.2 \% \\
\end{array}$ & 9.88 & $0.007 * *$ \\
\hline $\begin{array}{l}\text { Residence } \\
\text { Urban } \\
\text { Rural }\end{array}$ & $\begin{array}{l}89.3 \% \\
10.7 \% \\
\end{array}$ & $\begin{array}{c}90.8 \% \\
9.2 \% \\
\end{array}$ & 0.68 & 0.409 \\
\hline $\begin{array}{l}\text { Child's order } \\
\text { First } \\
\text { Middle } \\
\text { Last }\end{array}$ & $\begin{array}{l}52.7 \% \\
18.6 \% \\
28.7 \% \\
\end{array}$ & $\begin{array}{l}54.4 \% \\
21.9 \% \\
23.7 \%\end{array}$ & 3.92 & 0.14 \\
\hline $\begin{array}{l}\text { Income } \\
\text { Insufficient } \\
\text { Sufficient } \\
\text { Allow saving }\end{array}$ & $\begin{array}{l}3.4 \% \\
55.2 \% \\
41.5 \% \\
\end{array}$ & $\begin{array}{l}3.2 \% \\
65.4 \% \\
31.4 \% \\
\end{array}$ & 12.0 & $0.002 * *$ \\
\hline $\begin{array}{lll}\text { Parent(s)is/are } & \text { health care } \\
\text { worker } & & \\
\text { Yes } & & \\
\text { No } & & \\
\end{array}$ & $\begin{array}{l}16.4 \% \\
83.6 \%\end{array}$ & $\begin{array}{l}31.7 \% \\
68.3 \%\end{array}$ & 38.1 & $<0.001 * *$ \\
\hline
\end{tabular}

\section{Figure 4: General condition \&worries about health}

Excessivly wash his hands \& use sterilizers ask his parents to check his body...

look at the mirror to check his general look

Constantly ask if he look sick

Stomach pain headache

feel general pain

No longer able to carry out their usual daily...

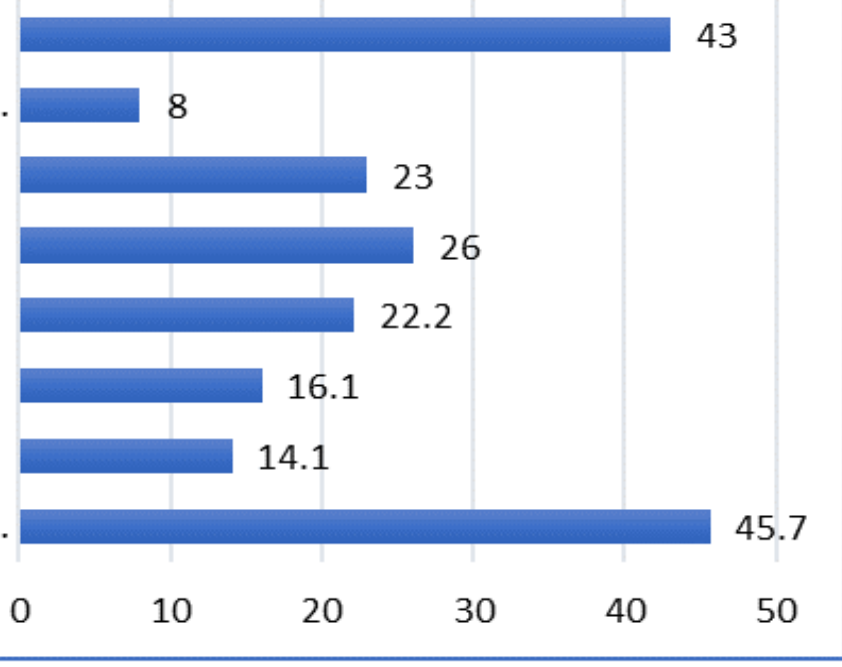


Table 3 demonstrates that there was significant relation between sex and mood and behavioral changes $(p<0.02)$.

Table (3): Relation between sociodemographic factors and mood and behavioral changes

\begin{tabular}{|c|c|c|c|c|}
\hline $\begin{array}{l}\text { Mood and behavioral changes } \\
\text { Socio-demographics }\end{array}$ & Yes $(\%)$ & No $(\%)$ & $x^{2}$ test & $P$-value \\
\hline $\begin{array}{l}\text { Sex } \\
\text { Male } \\
\text { Female }\end{array}$ & $\begin{array}{l}57.3 \% \\
42.7 \%\end{array}$ & $\begin{array}{l}63.5 \% \\
36.5 \% \\
\end{array}$ & 5.01 & $0.02 *$ \\
\hline $\begin{array}{l}\text { Age group } \\
6- \\
8- \\
10- \\
12-14\end{array}$ & $\begin{array}{l}16.7 \% \\
35.7 \% \\
20.5 \% \\
27.1 \%\end{array}$ & $\begin{array}{l}14.6 \% \\
38.3 \% \\
20.3 \% \\
26.8 \%\end{array}$ & 1.36 & 0.715 \\
\hline $\begin{array}{l}\text { School } \\
\text { Governmental } \\
\text { Private } \\
\text { International } \\
\end{array}$ & $\begin{array}{l}26.5 \% \\
59.4 \% \\
14.1 \% \\
\end{array}$ & $\begin{array}{l}28.2 \% \\
58.6 \% \\
13.3 \% \\
\end{array}$ & 0.49 & 0.782 \\
\hline $\begin{array}{l}\text { Residence } \\
\text { Urban } \\
\text { Rural } \\
\end{array}$ & $\begin{array}{l}91.3 \% \\
8.7 \%\end{array}$ & $\begin{array}{l}88.5 \% \\
11.5 \% \\
\end{array}$ & 2.9 & 0.087 \\
\hline $\begin{array}{l}\text { Child's order } \\
\text { First } \\
\text { Middle } \\
\text { Last }\end{array}$ & $\begin{array}{l}53.3 \% \\
21.3 \% \\
25.4 \% \\
\end{array}$ & $\begin{array}{l}55.6 \% \\
20.9 \% \\
23.4 \%\end{array}$ & 0.812 & 0.666 \\
\hline $\begin{array}{l}\text { Income } \\
\text { Insufficient } \\
\text { Sufficient } \\
\text { Allow saving }\end{array}$ & $\begin{array}{l}3.4 \% \\
64.4 \% \\
32.2 \% \\
\end{array}$ & $\begin{array}{l}3.2 \% \\
62.7 \% \\
34.1 \% \\
\end{array}$ & 0.537 & 0.765 \\
\hline $\begin{array}{l}\text { Parent(s)is/are health care worker } \\
\text { Yes } \\
\text { No }\end{array}$ & $\begin{array}{l}19 \% \\
81 \%\end{array}$ & $\begin{array}{l}21.4 \% \\
68.3 \%\end{array}$ & 1.13 & 0.287 \\
\hline
\end{tabular}

Figure 5 demonstrates that mood and behavioral changes were very notable as $70.5 \%$ of the total studied children showed changes but the most prominent change was the aggressive behavior of the children

\section{Figure 5:Mood \&behavioral changes}

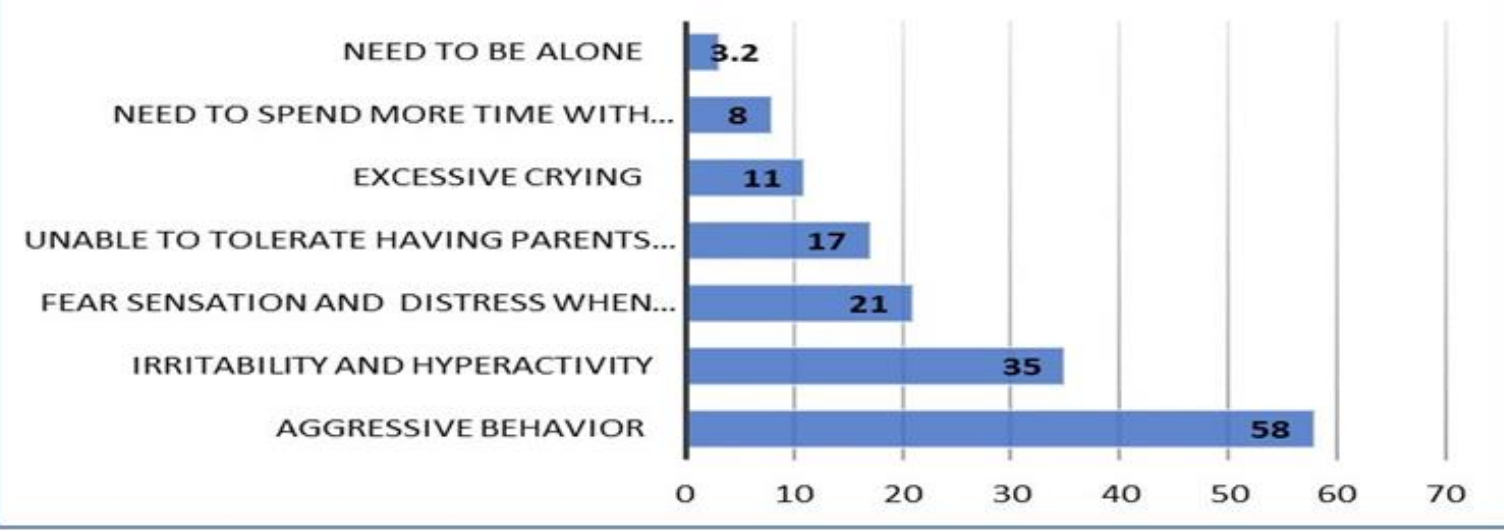

The current pandemic affected the concentration and focusing of the children, this could be recognized from the high percentage (89.6\%) of children asking a lot about COVID-19 pandemic "what is it?, Is it fatal?, What are the symptoms?, How can I get infection?". These worries negatively affected the children concentration, as $38.1 \%$ of parents stated that their children could not complete their assignments, $26.3 \%$ could not sit through a favorite movie or TV show and $24.3 \%$ could not answer simple questions. 


\section{DISCUSSION}

The COVID-19 pandemic presents the greatest test the world has faced since the Second World War. Physical distancing and lockdown measures, restrictions of movement and border closures, and surveillance strategies are all affecting children in myriad ways. The impact of the pandemic extends far beyond the sphere of physical health. The pandemic is having profound effects on children's mental well-being, their social development, their safety, daily activities, nutrition and sleep ${ }^{(9)}$.

The consistency of the psychological problem in children is very high and this was evident through the current study. The psychological distress due to quarantine is reflected on their sleep, eating, mood, behavior and concentration. In this study, most (around 96.4\%) of quarantined children showed some disorders regarding sleeping time, duration, quality of sleep, return to bedwetting, frequent nightmares, difficulty to fall asleep and avoiding bedtime and all these findings came in agreement with Chen et al. ${ }^{(10)}$ and Di Giorgio et al. ${ }^{(11)}$. Changes in children's sleep may be a result of school interruption and the children not having to wake up early, in addition to long leisure times, as well as the stopping of sports and social activities that deplete their energy, and this prompted children to stay up for long periods of time, as well as the stay of some parents at home due to the conditions of the ban that encouraged children to stay up late. Also, sleeping disorders may be due to extreme fear or anxiety about the corona pandemic. This explanation is supported by Di Giorgio et al. ${ }^{(11)}$ who stated that sleep timing strongly shifted $\sim 53$ min to go bed and $\sim 66$ min later than usual to wake up. These changes, together with reported difficulties of following routines, indicate a substantial breakdown in daily routines. This aspect is particularly relevant because one of the most protective factors in preserving both physical and psychological wellbeing in children is having a structured and pre-planned day ${ }^{(12)}$. The study also revealed changes in the eating pattern of children, where a large number neglected many meals and lost the desire for their favorite food and it became common to eat in late hours of the night. These changes may be due to several reasons, the most important of which is the change in sleep times, which necessitates staying up late and eating in late periods at night. Likewise, the nature of eating before the ban measures allowed eating fast food several times a week, but after the total ban measures were imposed and restaurants are closed, children became forced to eat home food that might not be their liking. Finally, some people may express their fear and anxiety with overeating or, conversely, losing Appetite.

Our findings were similar to that of Ammar et al. ${ }^{(13)}$ who stated that in contrast to the guidance of the World Health Organization ${ }^{(14,15)}$, people changed their eating behaviors, with increased consumption of unhealthy food, eating out of control, more snacking between meals and an overall higher number of main meals ${ }^{(16)}$. The negative changes in the majority of eating behaviors could be attributed to eating out of anxiety or boredom or an increase in mood-driven eating.

With regard to the psychological effects of the ban due to the corona pandemic, it was noticeable that the percentage of children who were constantly worried about their health increased, and this was reflected in their frequent looking in the mirror to see if they seemed healthy or not, as well as their request from their parents to measure their temperature, as well as their excessive use of sterilizers and excessive hand washing.

In addition to that, it has been observed that children have become more aggressive and have a constant feeling of fear and sadness. They cannot stay alone without their parents or sleep alone, and some of them have become preferring isolation. Likewise, the percentage of children who became stressed and could not stay to watch a TV program until its end and their ability to concentrate weakened, so they could not finish homework or answer simple questions at the same time that the questioning of the current pandemic intensified, what are its symptoms, and are they fatal. The results of our study were consistent with several studies in Asia which reported a higher prevalence of post-traumatic stress disorders (PTSD) after COVID-19 within the general population ${ }^{(17,18)}$ and problems with anxiety and depression ${ }^{(\mathbf{1 9 - 2 2})}$.

Other studies related to psychological impact in quarantined adults generally reported a high prevalence of symptoms of psychological distress like the present study but we investigated the impact in school children. These studies reported emotional disturbance, depression, stress, low mood, irritability, insomnia, post-traumatic stress symptoms, anger and emotional exhaustion. Quarantine studies also found a range of other feelings such as, confusion, fear, anger, grief, numbness and anxiety related insomnia ${ }^{(23-26)}$. A study on children also found that the mean post-traumatic stress scores were four times higher in children who had been quarantined to those who were not quarantined. Long term behavior changes after the quarantine period, such as vigilant hand washing and avoidance of crowds have been reported ${ }^{(27)}$.

\section{CONCLUSION}

This study concluded that the total lockdown measures that were followed during the corona pandemic had negative effects on children in terms of nutrition, sleep and the practice of daily life activities and increased feelings of fear and anxiety in children, which requires psychological management of these effects especially if the lockdown measures continued for another periods up till a vaccine or treatment for corona virus is reached. 


\section{LIMITATION OF THE STUDY}

It is a cross-sectional descriptive study depending on parent-reported outcomes, small sample sizes, low response rates, lack of appropriate comparison group, and generalizability.

\section{ACKNOWLEDGMENT}

The researchers extend their sincere thanks and appreciation to the Scientific Research Account Fund at Benha University for its financial and moral support to complete the research related to the research project, within the projects of young researchers (stage five). The researchers also have the honor to thank both Prof. Dr. Jamal Al-Saeed (President of Benha University), Prof. Dr. Nasser Al-Jizawi (Vice President for Postgraduate Studies and Research - Benha University) and Prof. Dr. Maher Hassab El Nabi Khalil (Advisor to the President of the University for Scientific Research and General Supervisor of the Scientific Research Account Fund At Benha University).

\section{REFERENCES}

1. Centers for Disease Control Prevention (2017): Legal authorities for isolation and quarantine. Centers for Disease Control and Prevention. http://ccionline.org/wp-content/uploads/2020/03/CDCLegal-Authorities-for-Isolation-and-Quarantine.pdf

2. UNICEF (2020): Key messages and actions for COVID-19 prevention and control in schools. https://www.who.int/docs/default-source/coronaviruse/keymessages-and-actions-for-covid-19-prevention-and-control-inschools-march-2020

3. Fiorillo A, Gorwood P (2020): The consequences of the COVID19 pandemic on mental health and implications for clinical practice. European Psychiatry, 63(1): 32-4.

4. Li S, Wang Y, Xue J et al. (2020): The impact of COVID-19 epidemic declaration on psychological consequences: A study on active Weibo users. Int J Environ Res Public Health, 17(6): 1-9.

5. Torales J, O'Higgins M, Castaldelli-Maia J et al. (2020): The outbreak of COVID-19 coronavirus and its impact on global mental health. Int J Soc Psychiatry, 66(4): 317-20.

6. Barbisch D, Koenig K, Shih $F$ (2015): Is there a case for quarantine? Perspectives from SARS to Ebola. Disaster Medicine and Public Health Preparedness, 9(5):547-53.

7. Center of Diseases Control (CDC) (2019): Coronavirus disease 2019 (COVID-19).Helping children cope. https://emergency.cdc.gov/coca/calls/2020/callinfo_072820.asp

8. Ammar A, Brach M, Trabelsi K et al. (2020): Effects of COVID19 home confinement on social participation and life satisfaction: Preliminary results of the ECLB-COVID19 International onlinesurvey. https://www.medrxiv.org/content/10.1101/2020.05.04.20072447v1 .full.pdf+html

9. United Nation (2020): Policy Brief. The Impact of COVID-19 on children. https://unsdg.un.org/ar/node/30314

10. Chen R, Chou K, Huang Y et al. (2006): Effects of a SARS prevention program in Taiwan on nursing staff's anxiety, depression and sleep quality: A longitudinal survey. Int J Nurs Stud., 43(2): 215-25.

11. Di Giorgio E, Di Riso D, Mioni G et al. (2020): The interplay between mothers' and children behavioral and psychological factors during COVID-19: An Italian study.https://link. springer.com/article/10.1007/s00787-020-01631-3

12. Brazendale $K$, Beets $M$, Weaver $R$ et al. (2017). Understanding differences between summer vs. school obesogenic behaviors of children: the structured days hypothesis. Int J Behav Nutr Phys Act., 14(1): 1-14.

13. Ammar A, Brach M, Trabelsi K et al. (2020): Effects of COVID19 home confinement on eating behavior and physical activity: Results of the ECLB-COVID19 international online survey. Nutrients, 12(6):1-13.

14. World Health Organization (2020): [Internet]. Food and nutrition during self-quarantine: what to choose and how to eat healthily; WHO Regional Office for Europe,UN City, Marmorvej 51, DK-2100 Copenhagen $\varnothing$, Denmark. Available from: https://www.euro.who.int/en/health-topics/disease-prevention/ nutrition/news/news/2020/3/food-and-nutrition-during-selfquarantine-what-to-choose-and-how-to-eat-healthily.

15. World Health Organization (2019): [Internet]. Available from: http://www.euro.who.int/en/health-topics/health emergencies/coronaviruscovid-19/novel-coronavirus-2019-ncovtechnical-guidance/food-and-nutrition-tips-during-self-quarantine.

16. NNEDPro (2020): Combatting COVID-19: A 10-point summary on diet, nutrition and the role of micronutrients. St. John's Innovation Centre, Cowley Road, Cambridge, CB4 0WS, UK2020. Available from: https://www.nnedpro.org.uk/post/combattingcovid-19.

17. Liu N, Zhang F, Wei C et al. (2020): Prevalence and predictors of PTSS during COVID-19 outbreak in China hardest-hit areas: Gender differences matter. Psychiatry Res., 287(112921).1-7.

18. Wang C, Pan R, Wan X et al. (2020): Immediate psychological responses and associated factors during the initial stage of the 2019 coronavirus disease (COVID-19) epidemic among the general population in China. Int J Environ Res Public Health, 17(5): 1-25.

19. Nguyen H, Nguyen M, Do B et al. (2020): People with suspected COVID-19 symptoms were more likely depressed and had lower health-related quality of life: The potential benefit of health literacy. J Clin Med., 9(4): 1-18.

20. Qiu J, Shen B, Zhao M et al. (2020): A nationwide survey of psychological distress among Chinese people in the COVID-19 epidemic: implications and policy recommendations. Gen Psychiatr., 33(2):1-3.

21. Cao W, Fang Z, Hou G et al. (2020): The psychological impact of the COVID-19 epidemic on college students in China. Psychiatry Res., 287(112934): 1-5.

22. Wang Y, Di Y, Ye J et al. (2020): Study on the public psychological states and its related factors during the outbreak of coronavirus disease 2019 (COVID-19) in some regions of China. Psychology, Health and Medicine, 25(3): 1-10.

23. Sprang G, Silman M (2013): Posttraumatic stress disorder in parents and youth after health-related disasters. Disaster Med Public Health Prep., 7(1): 105-10.

24. Reynolds D, Garay J, Deamond S et al. (2008): Understanding, compliance and psychological impact of the SARS quarantine experience. Epidemiol Infect., 136(7): 997-1007.

25. DiGiovanni C, Conley J, Chiu D et al. (2004): Factors influencing compliance with quarantine in Toronto during the 2003 SARS outbreak. . Biosecur Bioterror., 2(4): 265-72.

26. Lee S, Chan L, Chau A et al. (2005): The experience of SARSrelated stigma at Amoy gardens. Soc Sci Med., 61(9): 2038-46.

27. Cava M, Fay K, Beanlands $H$ et al. (2005): The experience of quarantine for individuals affected by SARS in Toronto. Public Health Nurs., 22(5): 398-406. 